\title{
Glaciers, snow and ski tourism in Austria's changing climate
}

\author{
Andrea FISCHER, ${ }^{1,2}$ Marc OLEFS, ${ }^{1,3}$ Jakob ABERMANN ${ }^{1,4}$ \\ ${ }^{1}$ Institute of Meteorology and Geophysics, University of Innsbruck, Innrain 52, A-6020 Innsbruck, Austria \\ E-mail: andrea.fischer@uibk.ac.at \\ ${ }^{2}$ Research Unit Mountain Research: Man and Environment (IGF), Austrian Academy of Sciences (ÖAW), Technikerstrasse 21a, \\ A-6020 Innsbruck, Austria \\ ${ }^{3}$ Central Institute for Meteorology and Geodynamics, Hohe Warte 38, A-1190 Vienna, Austria \\ ${ }^{4}$ Commission for Geophysical Research, Austrian Academy of Sciences, Dr-Ignaz-Seipel-Platz 2, A-1010 Vienna, Austria
}

\begin{abstract}
This study illustrates the relevance of cryospheric changes for, and their impact on, ski tourism in Austria. The results of several case studies on snow reliability, snow production and mass balance in glacier ski resorts in the Ötz and Stubai valleys are summarized. Climate data from Obergurgl (1936 $\mathrm{m}$ a.s.l.) in the Ötz valley are analyzed with respect to the amount and duration of natural snow cover and the possibility of snow production. A case study on Mittelbergferner focuses on the impacts of glacial recession on a ski resort and possible adaptation measures. From long-term glacier inventory and short-term mass-balance data, the effect of operating ski resorts on glaciers is investigated. At Obergurgl, the probability of both snow cover and snow production is $\mathbf{8 0} \%$ from December to March and decreases significantly in the months before and after this peak season. The interannual variability of snow cover and production is low during the main season and higher in other months. Year-to-year differences are larger than any long-term trend. Glacier ski resorts must adapt to shrinking glacial area and falling glacier surface. Covering the glacier with textiles reduces ablation by $60 \%$ and results in significantly less volume loss than on uncovered parts of the glacier. Neither the mass-balance comparison between groomed and ungroomed areas nor the comparison of long-term volume changes between 10 ski resort glaciers and $\mathbf{1 0 0}$ surrounding glaciers showed evidence for an impact of the operation of ski resorts on the glaciers.
\end{abstract}

\section{INTRODUCTION}

Glacial recession and changes in seasonal snowpack have been investigated worldwide to understand their effects on hydrology and sea-level rise. In addition to their hydrological impacts, changes in snow and ice affect the daily lives of the inhabitants of the densely populated Austrian Alps in two ways. First, seasonal snowpack and glaciers are a potential source of natural disasters, and decreases in the amount and duration of seasonal snowpack reduce maintenance costs for roads and protection infrastructure. Second, winter tourism is an increasingly important industry which relies on snow. This study focuses on the implications of cryospheric changes for winter tourism. The most important parameters are the amount and duration of seasonal snow cover, the feasibility of snow production and, for several ski resorts located on glaciers, the ongoing glacial recession.

\section{BACKGROUND}

Alpine tourism achieved economic importance during the 19 th century, when the construction of railways, roads and mountain huts provided easier access to the mountains. In Austria, alpine ski sports started in 1900. The first cable car on the Rax, near Vienna, was built in 1926; the Nordkettenbahn in Innsbruck was completed in 1927. The number of cable cars in the Alps increased to $\sim 60$ by 1940 and at an even faster rate after World War II (Bätzing, 2003). In the 1970s-80s, a period of glacier advances and generally positive glacier mass balances, ski resorts were built on glaciers themselves. As of 2009, 254 cable-car companies operate 3500 ski lifts in Austria, including those at eight glacier ski resorts (http://www.seilbahnen.at/presse/aktuell/ factsheet-winter). Snow production facilities cover twothirds of the total area of $254 \mathrm{~km}^{2}$ of ski slopes. The number of midwinter overnight stays and the resulting added value has increased, overtaking midsummer tourism by the 1970s (Bätzing, 2003). In the 1980s, demand for such overnight stays varied depending on the availability of natural snow, but in the 1990s it stabilized after the large-scale production of artificial snow gained widespread acceptance. Austrian ski resorts are located at a variety of elevations, from a few hundred $\mathrm{m}$ a.s.I. to $\sim 3450 \mathrm{~m}$ a.s.l. For glacier ski resorts, the seasons with the highest number of visitors are OctoberDecember and March-May; at lower elevations, the peak season runs from December to the Easter holidays. With few exceptions, the resorts are busier in midsummer than in midwinter, mostly due to attractions such as downhill mountain-biking runs or ice caves. Climatic and economic change has dramatically affected the population of the Alpine valleys. The Ötz valley population decreased by $31 \%$ between 1817 and 1900 due to industrialization and the abatement of traditional agriculture (Bätzing, 2002). Since 1900, and in contrast to other remote rural regions of Europe, the population has increased, with the highest growth rates in the 1930s and 1970s, the periods of most rapid cable-car construction.

Several authors have analyzed the effects of climate change on Alpine tourism in summer. Behm and others (2006) used questionnaires to analyze the impact of climate change on alpine summer sports, finding that infrastructure in high alpine regions requires more maintenance as permafrost degrades and that dangers to alpinists (e.g. rockfall) are generally increasing. Diolaiuti and others (2006) investigated summer skiing at Vedretta Piana. 
Smiraglia and others (2008) analyzed two case studies of glacier changes and their impacts on mountain tourism in the Italian Alps, one at the summer ski resort Vedretta Piana and the other at the ice-contact lake Miage.

Winter tourism is very closely linked to specific climatic parameters governing the availability of winter snow cover or the possibility of snow production. Without sufficient snow cover, it is impossible to ski, snowboard or pursue other winter sports. Techniques of slope preparation and snow production have developed rapidly during recent decades, but so have demands on the ski tracks. Today, $\sim 0.30 \mathrm{~m}$ of snow depth is necessary to prepare ski runs. Since the produced snow is more compact and resistant to mechanical stresses (Fahey and others, 1999; Fauve and others, 2002), most ski tracks in Austria are covered with a mix of produced and natural snow. Usually at the beginning of the ski season a stable base layer of snow is produced on ski slopes. Snow production at the beginning of the season is thus an adaptation not only to climate change, but also to increased stress on this base layer. Modern snow production facilities allow the production of a skiable snow cover within 3 days under suitable meteorological conditions.

The various studies of worldwide trends in terrestrial snow cover have shown no broad agreement. Derksen and LeDrew (2000) summarized the results of eight studies in North America and one in the former USSR. Snow cover increased in three regions, decreased in four and two studies did not show a significant trend. Henderson and Leathers (2009) found an apparent, but not significant, negative trend in the extent of the European snow cover. McCabe and Wolock (2009) found no long-term increasing or decreasing trend in the snow water equivalent of the snow cover in the western United States by modeling the snow cover between 1900 and 2008. Since the 1970s, the snow-covered area and the snow water equivalent have decreased (McCabe and Wolock, 2009, 2010). Wulder and others (2007) investigated the variability of the snow-covered area of central Canada with passive microwave sensors between 1978 and 2002. They found a relationship between temporal variability in snow water equivalent (SWE) values and vegetation and stated that the spatial structure in the temporal variability of SWE values changes through time.

The snow cover in Switzerland has been the subject of several studies. Laternser and Schneebeli (2003) found a statistically significant decrease in snow depth, snow-cover duration and number of snowfall days. Scherrer and others (2004) showed that these trends are mainly related to local temperature increases. Beniston (1997) stated that the sensitivity of the snowpack to temperature changes diminishes at altitudes above $1750 \mathrm{~m}$; however, a sensitivity analysis of snow patterns in Swiss ski resorts showed a large decrease in snow depth and duration for all altitudes (Uhlmann and others, 2009). Lopez-Moreno and others (2009) modeled a remarkable decline of snowpack for future climate scenarios in the Pyrenees. As summarized by Beniston and others (in press), the interannual variability of the parameters related to snow cover is high and winters with abundant snow will also occur in a much warmer climate.

For Austria, Hantel and others (2000) investigated data from 84 stations to find the sensitivity of snow-cover duration to climate warming. They found that a $1^{\circ} \mathrm{C}$ temperature increase may reduce the length of the snowcover period in the Austrian Alps by 3 weeks in winter and 6 weeks in spring. Schöner and others (2009) investigated long-term trends of snow depth at specific stakes near Rauriser Sonnblick and found a decrease in snow depth since the 1950s. Fliri (1992) found no general trend in snowcover duration in Tirol until the early 1990s.

A number of recent studies have investigated the impact of climate change on winter tourism, especially ski tourism. Abegg and others (2007) analyzed 666 winter ski resorts in the Alps. They stated that $91 \%$ of ski resorts are at present naturally snow-reliable. They calculated a positive relationship between elevation and snow reliability due to temperature. As stated by Steiger and Mayer (2008), ski tourism depends not only on snow reliability, but also on potential artificial snow production. They found that a 100 day ski season would be possible even with an increase in temperature, but at higher cost than today.

Breiling and Charamza (1999) investigated the climate sensitivity of Austrian ski resorts by analyzing data from 30 snow stations collected between 1965 and 1995. They did not include the possibility of artificial snow production.

\section{METHODS AND DATA}

\subsection{Data on climate and snow cover in the Austrian Alps}

Climate change in the Austrian Alps is well documented in the HISTALP (historical instrumental climatological surface time series of the greater alpine region) data (http:// www.zamg.ac.at/HISTALP/). The long-term instrumental station data of the Alps and surroundings were qualitychecked and homogenized and are provided for specific stations and as a grid. The types and numbers of the climate parameters included in the HISTALP data vary from station to station, but are restricted to monthly values of air pressure, air temperature, precipitation and sunshine duration. From the HISTALP data, Auer and others (2007) found an increase of $0.002-0.007^{\circ} \mathrm{Ca}^{-1}$ between 1950 and 1975 and $0.047-0.057^{\circ} \mathrm{Ca}^{-1}$ between 1975 and 2000 in four different areas of the greater Alpine region. Both valley and mountain stations in the Alps show similar temperature trends, but precipitation trends differ for specific periods and regions.

The HISTALP data do not include snow-cover or airhumidity data, nor do they include data with hourly resolution. Since snow production takes place during the few hours when it is cold enough, data from the weather station in Obergurgl were used in this study to analyze the amount of natural snow cover and the possibility of snow production. This station has been operated since 1952 by the Austrian weather service and the University of Innsbruck in the Ötztal Alps at 1938 ma.s.l. (Fig. 1). Among other parameters, $2 \mathrm{~m}$ air temperature, relative humidity and snow cover are measured manually by the observer. The temperature is measured in a standard weather hut. These data are available for several observation times each day and as daily mean values. As well as the observer, an automatic weather station (TAWES, www.zamg.ac.at) has been operating since 1987, collecting hourly data.

As stated by Olefs and others (2010), air temperature and relative humidity of the manual period were measured using thermo-hydrographs from Fuess and Thies, liquid thermometers from Schneider and Janaer as well as the Assman Psychrometer. Linearized thermistors from Kroneis and Logotronic and a hair hygrometer from Lambrecht were used after 1987 in the automatic weather station. The 


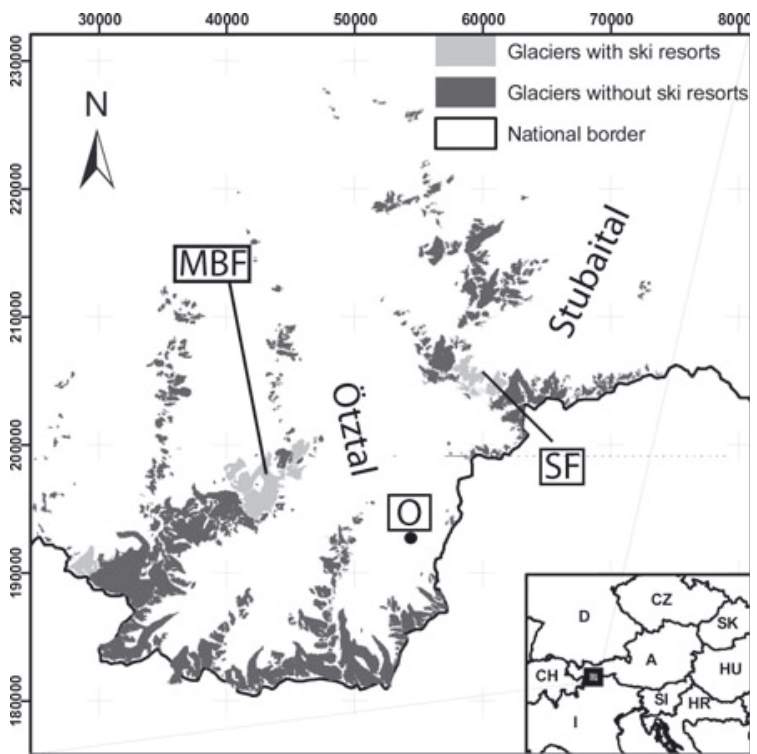

Fig. 1. Map of the study area, Ötz valley and Stubai valley, in the Austrian Alps. The glaciers with ski resorts are shown in light gray, other glaciers in dark gray. MBF: Mittelbergferner, O: Obergurgl; SF: Schaufelferner.

measurement accuracies are $\pm 1 \%$ for relative humidity and $\pm 0.2^{\circ} \mathrm{C}$ for air temperature. All data were manually qualitycontrolled, removing outliers and physically unrealistic values. Missing values were discarded from the trend analysis. Since the beginning of the measurements, the annual mean of the air temperature has increased by $1.2^{\circ} \mathrm{C}$. The station is located close to the glaciers Hintereisferner and Kesselwandferner, where mass balances measured directly since $1952 / 53$ result in a cumulative specific mass balance of $-31.7 \mathrm{~m}$ w.e. for Hintereisferner (Fischer, 2010) and $-5.7 \mathrm{~m}$ w.e. for Kesselwandferner between 1953 and 2009 (Fischer, unpublished information).

\subsection{Modeling snow production from climate data}

To produce snow, water droplets released from snow guns under high pressure must freeze. Both air temperature and relative humidity, among other factors, are important to this process. Wet bulb temperature is the single atmospheric parameter that depends on both the dry air temperature and the relative humidity of the air and thus gives a direct measure of the amount of energy a droplet can lose in the air (Olefs and others, 2010; supplementary material is available at http://imgi.uibk.ac.at/IceClim/papers/artifsnow/artifsnow. html). In brief, for a given temperature, the drier the air, the more snow can be produced. The conditions for snow production are the same for a dry air temperature of $-2{ }^{\circ} \mathrm{C}$ and a relative humidity of $90 \%$ and $+1{ }^{\circ} \mathrm{C}$ and $45 \%$, both of which correspond to a wet bulb temperature of $-2.5^{\circ} \mathrm{C}$. Snow production is possible at wet bulb temperatures of $<-2^{\circ} \mathrm{C}$ (Olefs and others, 2010). Below this threshold, the lower the wet bulb temperature, the more snow can be produced.

\subsection{Methods to measure glacier mass changes}

Glacier mass changes can be measured on an annual basis by the direct glaciological method (Hoinkes, 1970), which uses ablation stakes and accumulation measurements in snow pits. With ablation stakes, variations of ablation can also be measured with daily resolution in test fields a few

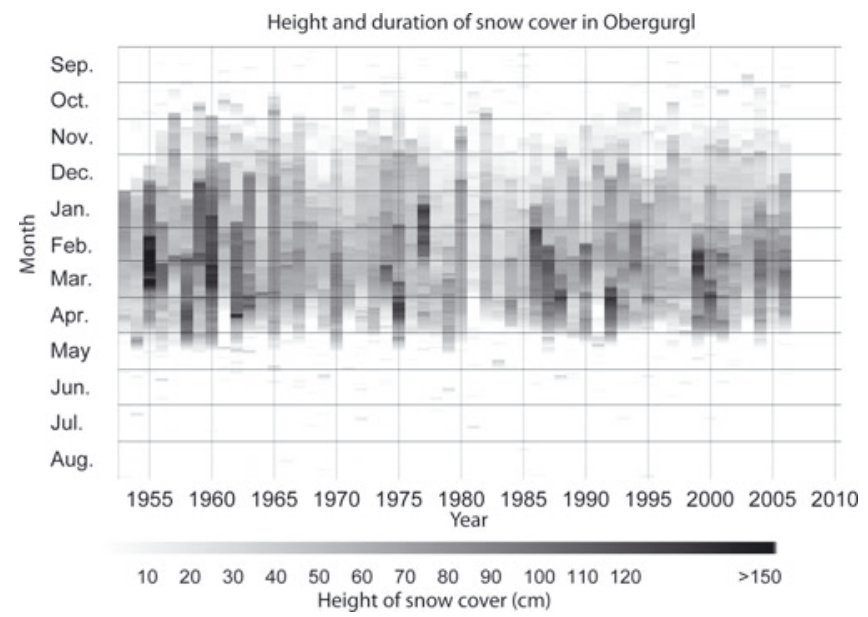

Fig. 2. Variability of natural snow cover 1952/53-2006 in Obergurgl.

meters in diameter. The stake measurements are accurate to within a few centimeters (Kuhn and others, 1999). The geodetic method (Hoinkes, 1970) is perfectly suited to study the mass changes of a larger sample of glaciers during a period of one or more decades. This method is based on calculation of the volume change within a certain period by subtracting digital elevation models acquired at the beginning and end of the period.

\subsection{Glacier inventories of the Austrian Alps}

Glaciers in Austria have retreated since the end of the Little Ice Age, with short interruptions in the 1920s and 1980s (Gross, 1987), resulting in a net loss of $>50 \%$ by area. The recession is documented in three glacier inventories conducted in 1969 (Patzelt, 1980), 1998 (Lambrecht and Kuhn, 2007) and 2006 (Abermann and others, 2007). The accuracy of the data was investigated by Würländer and Eder (1998). These glacier inventories include glacier area and surface elevation data. According to Abermann and others (2007), sample glaciers in the Ötztal Alps lost $12 \%$ of their area over 1969-97 and 8.3\% of their area over 1997-2006. The glacier surface elevation dropped over these periods by an average of -0.6 and $-1.0 \mathrm{ma}^{-1}$, respectively.

\section{RESULTS}

\subsection{Variability of winter snow cover in Obergurgl}

The duration and height of the winter snow cover shows high interannual variability (Fig. 2). No significant trend in duration or height of snow cover is evident from this time series. From 1953 to 2007, the probability of continuous snow cover was calculated for every day of the year (Fig. 3). We calculated the probability as the percentage of years which show snow cover for a given day. Thus, the probability is defined as $100 \%$ for the days that showed snow cover in all investigated years. Snow-cover occurrence is most likely in January and February, when it is typical for all Austrian ski resorts. In Obergurgl, natural snow cover is almost certain during this period. In October, November and April, the probability of snow cover sharply decreases.

Two periods were chosen to compare the most recent decades with previous ones. The interannual variability is high, so in climatology 30 year periods are investigated to 


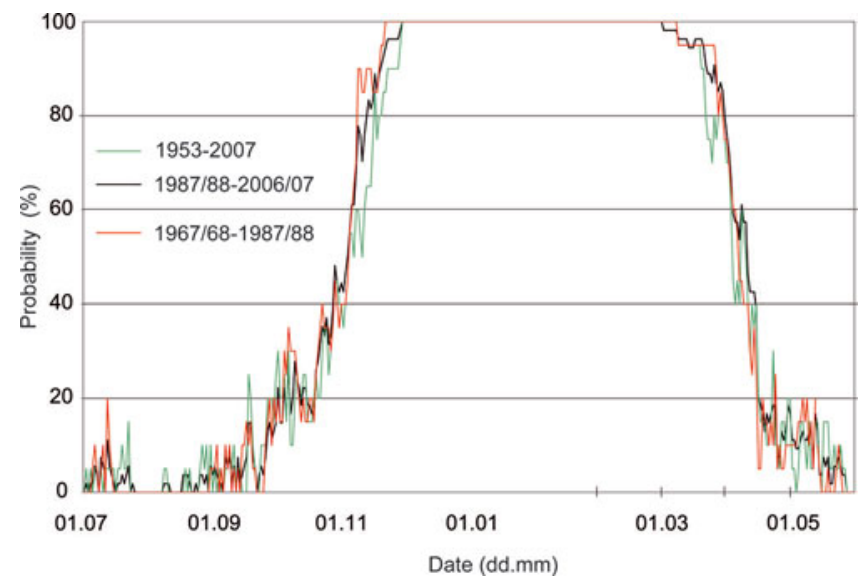

Fig. 3. Measured probability of snow cover in Obergurgl for different days in the periods 1967/68-1987/88, 1987/88-2006/07 and 1953-2007.

find trends. For shorter periods, the interannual variations are larger than the effects of a long-term trend. For Obergurgl, only 54 years of data were available for the analysis. Thus two 20 year sub-periods, the most recent and the previous one, were chosen (1987/88-2006/07 and 1967/ 68-1987/88) to analyze variations in the number of days with natural snow cover. It turned out that there is no significant difference in snow-cover probabilities over the two sub-periods. Most differences occur in months with a low probability of snow cover, when air temperatures are close to $0^{\circ} \mathrm{C}$ and therefore close to the transition from snow to rain.

\subsection{Variability of snow production in Obergurgl}

Analyzing the time series of wet bulb temperatures at Obergurgl as described by Olefs and others (2010) with the nonparametric, linear Mann-Kendall trend test (Mann, 1945; Kendall, 1955), we found that interannual variability of the wet bulb temperatures is lower than the variability of the natural snow cover (Fig. 4). The length and distribution of the periods in which snow can be produced also varies. During peak season, snow can be produced on $80 \%$ of the

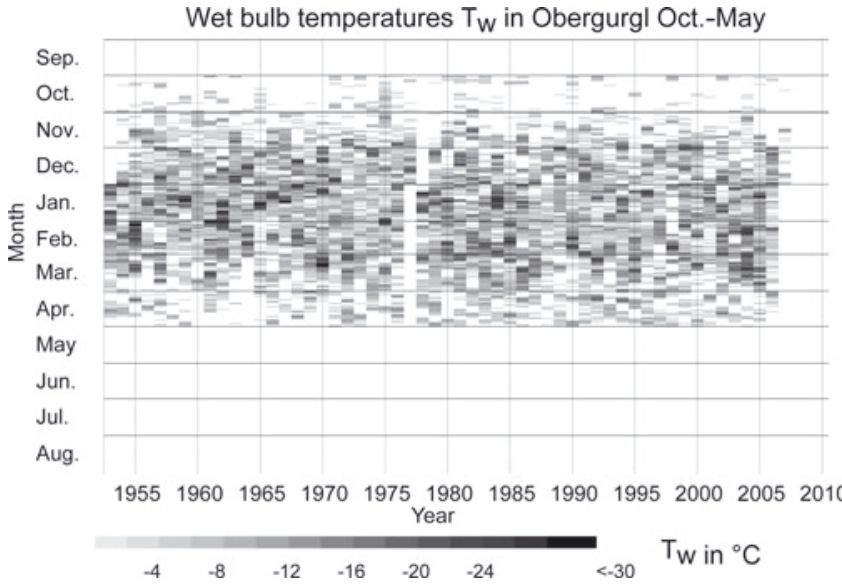

Fig. 4. Variability of potential snow production 1952/53-2005/06 in Obergurgl. The wet bulb temperature is shown in a grayscale; values above $-2^{\circ} \mathrm{C}$ when snow production is not possible are shown in white. No data were recorded from January to November 1978

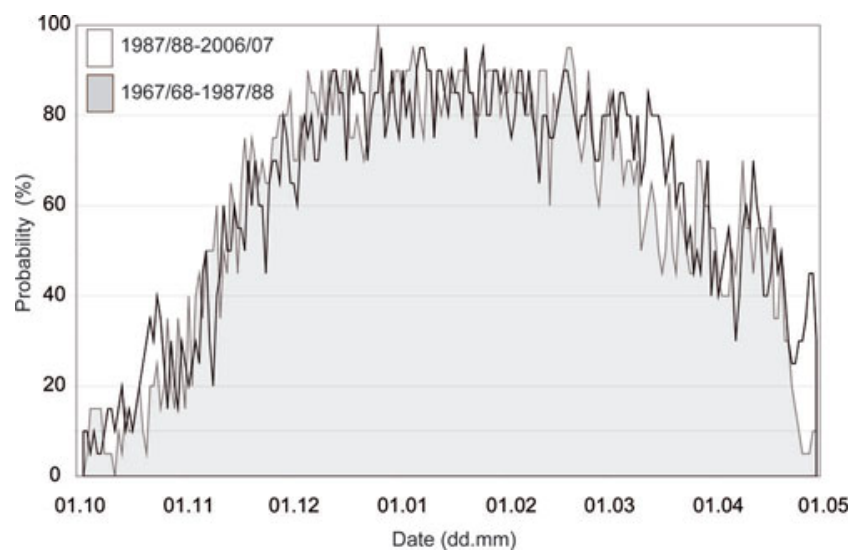

Fig. 5. Calculated probability of artificial snow production in Obergurgl for different days in the periods 1967/68-1987/88 and 1987/88-2006/07 based on the wet-bulb temperature threshold value of $-2^{\circ} \mathrm{C}$

days. The daily probabilities for wet bulb temperatures below $-2{ }^{\circ} \mathrm{C}$ are similar to the probabilities for natural snow cover and do not change significantly between 1967/681987/88 and 1987/88-2006/07 (Fig. 5).

\subsection{Ski resorts on glaciers and climate change}

Glacier ski resort infrastructure is partly located on the glacier, moving with the ice, and partly fixed on ice-free ground. For those ski slopes that connect the highest and lowest lift stations, a specific inclination and width, and a skiable snow or firn cover is required. The inclination for easy ski slopes must be $<25 \%$, for medium ski slopes $40 \%$. Usually the runs are $>8 \mathrm{~m}$ wide. Also, the area must not be vulnerable to avalanches and rockfalls. Lift pylons are mounted on $\mathrm{H}$-shaped metal bars dug into the ice. The pylons can be adjusted to compensate for ice flow of up to several meters by shifting and tilting the pylon. The pylons are also vertically adjustable to compensate for variable seasonal snow cover; this flexibility is especially important for T-bars where the distance to the ground must be kept within certain limits. For T-bars, the inclination of the lift trail should be $<40 \%$, for safety reasons.

For glacier ski resorts, a number of climate-related glaciological parameters are relevant:

amount and duration of seasonal snow cover,

size of firn-covered areas,

number and size of crevasses,

direction and velocity of ice flow,

debris cover and the position of the emergence zone,

changes in glacier area,

changes of surface altitude, and

changes of surface roughness.

In the early 1970s-80s, positive mass balances were measured for many glaciers in Austria, leading to volume gains and glacier advances. These endangered resort infrastructure: for example, ice had to be removed from Schaufelferner in the Stubai Alps to prevent the destruction of a station building near the advancing tongue. High iceflow velocities and the high number and large size of 


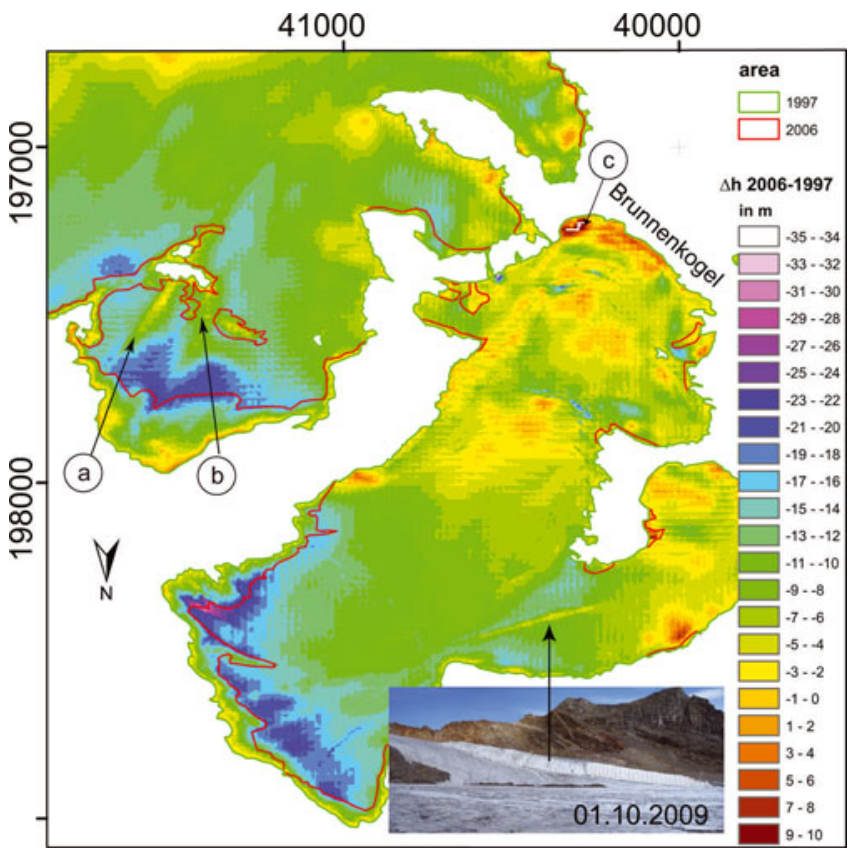

Fig. 6. Surface elevation change between 1997 and 2006 for the area shown in Figures 8 (a and b) and 7 (c).

crevasses made the positioning of lift pylons difficult. The pylons had to be adjusted and relocated more frequently than they do today. Today, the surface ice-flow velocities of Austrian glaciers have fallen from a measured maximum of $>100 \mathrm{~m} \mathrm{a}^{-1}$ by a factor of 10 (Abermann and others, 2007). On most ski lifts, the ice-flow velocities are $<10 \mathrm{~m} \mathrm{a}^{-1}$. This would lead to less frequent repositioning of the pylons, but, at the same time, surface ablation increased significantly, to a maximum of $\sim 4 \mathrm{~m}$ w.e. More frequent reanchoring of the pylons is therefore necessary, even though the horizontal and vertical position of the pylons may still be within acceptable limits. The recession of firn area and less frequent summer snowfalls (Fischer, 2010) resulted in less or no summer skiing. Today, more seasonal snow cover is needed to open the ski season in autumn than in the 1970s and 1980s, when the firn cover was larger and the debris cover less. Except for the extreme summer of 2003, crevasses are smaller than in the 1970s and 1980s.

Most ski runs are located partly on the glacier and partly on ice-free ground. The points of transition between infrastructure on rock and ski runs on glaciers are critical points for ski resorts, because the sinking of the glacier surface causes changes in the relative elevation of infrastructure on and off the glacier. Thus the ski runs may be disconnected at the glacier margins, and access to or from lift stations is complicated. Although the mean ice thickness change for Austrian glaciers is just $-1 \mathrm{ma}^{-1}$, local surfaceelevation changes reach $8 \mathrm{ma}^{-1}$ (Fischer, unpublished information). Figure 6 shows an example of these problems from Mittelbergferner, which are quite typical for glacier ski resorts in Austria. The ice thickness change between 1997 and 2006 is largest $(-35 \mathrm{~m})$ in the lowest parts of the glacier. The upper parts show surface subsidence as well, even though the mass balance there is positive in most years, as the glacier surface can fall as a result of ice flow or densification processes. Figure 7 shows the summit of Brunnenkogelferner. The top station in the background is built on rock; the ski run is located on ice. The subsidence of

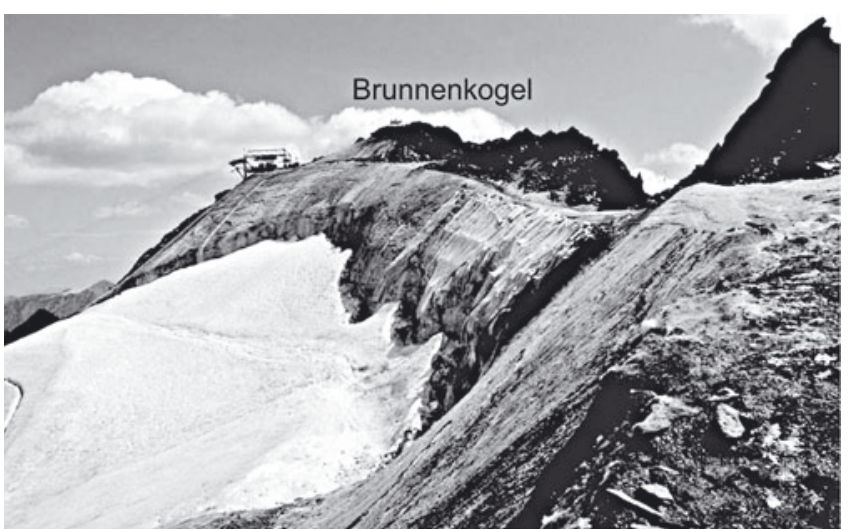

Fig. 7. Ski trail and mountain station of a lift on the upper margin of Brunnenkogelferner on 27 August 2003 (3440 m a.s.l.).

the main glacier surface below the bergschrund and the steepening of the slope above the bergschrund prevent direct access from the top lift station unless enough snow is present to make it possible to fill the depression. A small ski run leads along the ridge, but over the past few years its width has been reduced by melt at the steep slopes. Additionally, the ridge is exposed to wind and falling rocks which aggregate on the flat ski run. The albedo is thus reduced, which promotes melting until the debris cover is thick enough to protect the snow (Takeuchi and others, 2000). Adaptation measures are applied to the area as described below.

When adaptation measures are not applied, the glacier melts and exposes bare rocks and gravel. As a result, surface roughness increases and a larger base layer is necessary to open the ski season. Also, the temperature of the gravel or rock surface is higher, so falling snow melts faster on bare ground than on the glacier. On some glaciers, the appearance of rock ridges forces the relocation of ski runs (Fig. 8).
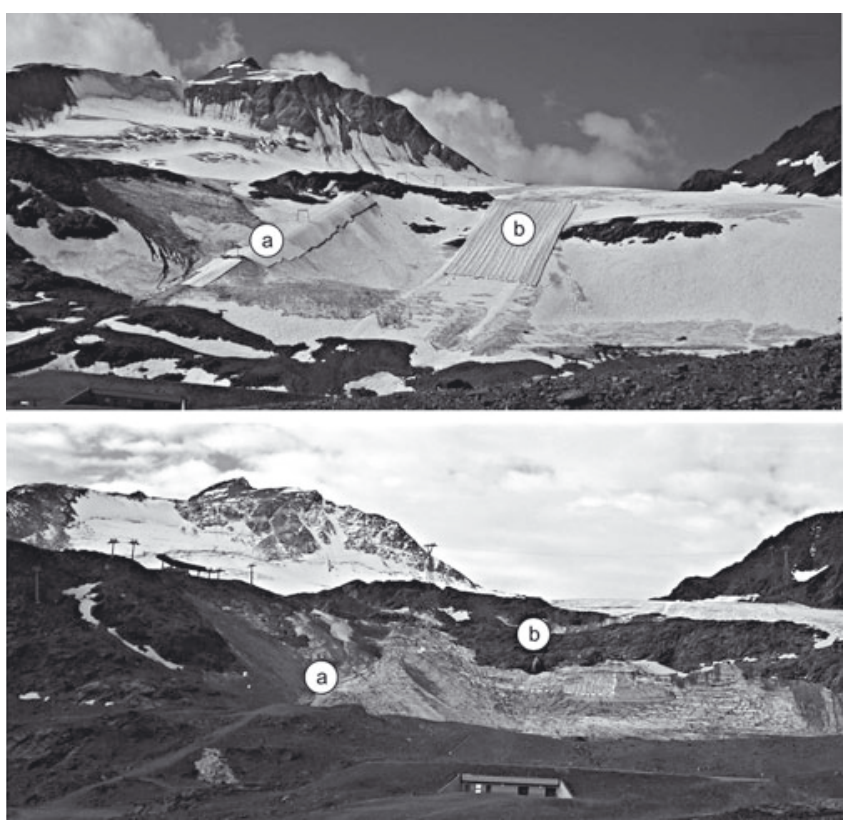

Fig. 8. Ski trails on Mittelbergferner on 4 August 2004 (top) and 1 October 2009 (bottom) at 2800 ma.s.l. The lift is marked a and the ski run $b$. 


\subsubsection{Adaptation measures}

The construction and maintenance of infrastructure at high altitudes is costly. Climate-change adaptation measures in ice-covered areas are necessary and follow two strategies. First, possible or likely scenarios of glacier changes are considered during the planning phase, so that such changes will not hinder the operation of the resort. Second, if existing structures cannot or can only at high cost be adapted, glacial recession is locally delayed by applying glacier covers or by snow farming. Snow farming is the management of natural and produced snow by controlled relocation.

Figure 8 shows an example of an adaptation process on Mittelbergferner. When the T-bar was constructed in the 1980s, the location of the rock ridge was not known. The lowest part of the lift trail steepened after the rock ridge blocked the flow of ice towards the lowest part of the glacier. The lift (a in Fig. 8) and the ski run (b in Fig. 8) were covered with textiles to keep the inclination small and the area covered with ice. Once ice melt increased the size of rock outcrops, construction of a cable-car pylon became possible, and the T-bar was replaced by a cable car on a new line. This line could not have been built before the ice melted, and is designed to cope with further glacial recession after a survey of ice thickness within the area. The ski slope was relocated to the left.

Technical measures to reduce volume loss or even increase glacier volume locally for a short period include relocating snow at the beginning of the ablation season and covering the glacier with textiles. Covering the glacier was observed to reduce the ablation by $60 \%$ from 2003 to 2008 (Olefs and Fischer, 2008). The actual effect of the cover, which is installed at the beginning and removed the end of the ablation season, depends on melt rate, elevation, solar radiation and accumulation in the area (Olefs and Lehning, 2010). Mass gain can only be achieved when enough snow is accumulated during the winters. A local volume gain can be achieved by relocating snow from periglacial areas with a snowcat. For some specific locations, triggering avalanches or installing wind brakes to force the deposition of drifted snow has the same effect. After several years of covering the glacier, the covered area is several meters higher than the uncovered glacier surface. The photograph in Figure 6 shows a covered lift trail where the glacier surface is $\sim 6-8 \mathrm{~m}$ higher than the surrounding uncovered area. The decrease in volume loss is also evident from the 1997-2006 volume change map: in the covered area of the photo, indicated by the arrow in Figure 6, the volume loss is $\sim 2.5 \mathrm{~m}$; in the surroundings, the surface elevation decreased by $5-15 \mathrm{~m}$, although the covering started as recently as 2004. Covering the glacier for just three ablation seasons had a clear effect on volume change in $<9$ years.

\subsubsection{Effect of ski-slope grooming on glacier mass balance}

Grooming snow increases snow density (Fauve and others, 2002) initially, until the structure of the snow changes in a way that alters the mechanical and thermodynamical properties of the snow (Olefs and Obleitner, 2007). The grooming influences only $\sim 0.20 \mathrm{~m}$ of the upper surface. After periodical grooming, the mean density was observed to be $450 \mathrm{~kg} \mathrm{~m}^{-3}$, with a maximum density of $550 \mathrm{~kg} \mathrm{~m}^{-3}$. Skiing enhances the effect, because the pressure per unit area is higher for a skier than for a snow groomer. The density increase is highest below the steel treads of the snow groomer. Grooming causes a depression between side-walls with a typical elevation difference of about $0.30-1.00 \mathrm{~m}$. In winter, groomed surfaces were observed to be mechanically more robust and experienced less wind erosion than natural snow surfaces at high altitudes in the Austrian Alps. At such altitudes, the snow is cold and nearly no melt occurs, so no snow crust develops that could effectively reduce wind drift.

Periodical grooming of snow in winter leads to a small additional accumulation by reducing wind erosion and encouraging wind-caused snowdrift from natural surfaces towards the depression of groomed surfaces. In 2005 this small surplus of accumulation was observed to prolong the snow cover of the glacier surface for a few days. Stake measurements (Hoinkes, 1970) of groomed and ungroomed areas on Schaufelferner showed a melt reduction of $6 \%$ for one ablation season. The ablation of ungroomed and groomed areas differed by $\sim 0.10 \mathrm{~m}$, which is close to the measurement error. Relative to other factors governing mass balance, the grooming of slopes in winter has no significant effect on mass balance. Today, summer skiing is rare, so ski slopes are not groomed between May and September or October. The injection of liquid water enhances the mechanical resistance of the snow, but the amount of injected water is too small to have a significant impact on mass balance (Olefs and Fischer, 2008). As with all adaptation measures, effective grooming requires maintenance.

\subsubsection{Volume changes of glaciers with and without ski resorts}

To investigate the long-term impact of ski resorts on glacier volume change, the volume changes at ski resorts were compared with a large sample of glaciers in the Stubai and Ötztal Alps (Fig. 1). Since it is not easy to separate the impact of ski resorts on mass balance from the natural sources of mass-balance variability, the volume changes of glaciers at ski resorts were compared with those of similar glaciers nearby. Since glacier ski resorts have operated for 30-40 years, any long-term effects should be evident. Ski resorts operate on 10 glaciers, i.e. $10 \%$ of the sample of 100 glaciers shown in Figure 1.

From 1969 to 1997 and 1997 to 2006, neither the mean ice thickness nor the relative area changes in ski resorts differed significantly from those of the other glaciers (Table 1). The relative loss of area was $11.5 \%$ on ski resort glaciers and $15.4 \%$ for all glaciers from 1969 to 1997. Between 1997 and 2006, data were available for only 84 of the 100 glaciers. The area of the sample of 84 glaciers shrank by $8.3 \%$, and that of the ski resort glaciers by $6.6 \%$. The ski resort glaciers lost less area than the surrounding glaciers over both periods. The mean ice thickness change over 1969-97 was $-8.1 \mathrm{~m}$ in ski resorts, and $-8.5 \mathrm{~m}$ on the sample glaciers. Between 1997 and 2006, the ice thickness decreased by 7.2 and $8.2 \mathrm{~m}$ at ski resorts and sample glaciers, respectively. In both periods, the ice surface in ski resorts fell less than the surface on nearby glaciers.

It must be noted that the topographic properties of the 10 ski resort glaciers and the 100 sample glaciers vary. The ski resort glaciers are mainly exposed to the north, which is the case for only $50 \%$ of the total sample. These systematic differences must be taken into account when interpreting the results. Nevertheless, the data suggest that ski resorts do not significantly affect volume changes of the glaciers. 
Table 1. Comparison between the area and volume changes of all glaciers in the Stubai and Ötzal region and those of glaciers within ski resorts

\begin{tabular}{|c|c|c|c|c|c|c|}
\hline & $\begin{array}{c}\Delta h \\
1969-97\end{array}$ & $\begin{array}{c}\Delta h \\
1997-2006\end{array}$ & $\begin{array}{c}\Delta A \\
1969-97\end{array}$ & $\begin{array}{c}\Delta A \\
1997-2006\end{array}$ & $\begin{array}{c}\Delta A \\
1969-97\end{array}$ & $\begin{array}{c}\Delta A \\
1997-2006\end{array}$ \\
\hline & $\mathrm{m}$ & $\mathrm{m}$ & $\mathrm{km}^{2}$ & $\mathrm{~km}^{2}$ & $\%$ & $\%$ \\
\hline Glaciers in ski resorts & -8.1 & -7.2 & -2.9 & -1.5 & -11.5 & -6.6 \\
\hline All Ötztal and Stubai glaciers & -8.8 & & -37.3 & & -15.4 & \\
\hline 84 Ötztal and Stubai glaciers & -8.5 & -8.2 & -17.6 & -10.5 & -12.2 & -8.3 \\
\hline
\end{tabular}

\section{SUMMARY AND CONCLUSIONS}

For the growing Austrian winter tourism industry, the most important cryospheric parameters are the presence and size of natural snow cover complemented by artificial snow production capacity. The interannual variability of duration and amount of snow cover is high. For the main ski season, from December to March, analysis of climate data from Obergurgl showed that the probability of winter snow cover within the observed period is $100 \%$. Before and after this peak, the probability of snow cover drops quickly. Snow cover in October, November, April and May is more sensitive to climate change and shows higher interannual variability.

The snow production in Obergurgl was $80-90 \%$ reliable during the main ski season over the past decade, with few exceptions. The daily probability of suitable meteorological conditions for snow production is lower than that of the occurrence of natural snow cover, which is $100 \%$ during the main season. But since just 3 days of snow production are sufficient for a skiable base layer, the snow production is generally reliable. The season when snow production is reliable is shorter than the season of natural snow reliability. The interannual variability of both snow cover and produced snow dominates signals that may be present over longer timescales. Significant trends in seasonal snow cover due to the measured increase in air temperature of $1.2^{\circ} \mathrm{C}$ are not evident from the analysis. Therefore, winter tourism requires strategies to cope with winters with less snow or shorter periods of snow cover, independent of climatic change potentially resulting in more frequent occurrence of these winters.

Ski resorts on glaciers must adapt their infrastructure to glacial recession. Although the mean annual fall in glacier surfaces in Austria is only $1 \mathrm{ma}^{-1}$, subsidence rates can be much higher at specific locations. Measures are applied to keep the altitude of the surface constant by decreasing ablation or increasing accumulation. Covering the glacier with textiles results in a $60 \%$ decrease in ablation. Snow groomers, controlled avalanches and the utilization of wind drift may be applied to locally increase accumulation. All these measures are applied on a small spatial scale for several years. They are applied to delay the mass loss for a few years, until other solutions are feasible. The resulting decrease in volume loss is evident in the volume change data (1997-2006).

Glacier ski resorts have operated in Austria for 30-40 years, and their impact on glaciers is discussed over this time period. The comparison between groomed and ungroomed surfaces and between $10 \mathrm{ski}$ resort glaciers and 100 surrounding glaciers showed no negative impact of the operation of ski resorts.

\section{ACKNOWLEDGEMENTS}

We address special thanks to J. Lang for his help in field and office, and the Central Institute for Meteorology and Geodynamics in Innsbruck (ZAMG) for providing the climate data for Obergurgl. We thank F. Pellet and G. Markl for their help in preparing the figures.

\section{REFERENCES}

Abegg, B., S. Agrawala, F. Crick and A. de Montfalcon. 2007. Climate change impacts and adaptation in winter tourism. In Agrawala, S., ed. Climate change in the European Alps: adapting winter tourism and natural hazards management. Paris, Organization for Economic Cooperation and Development. Environment Directorate, 25-60.

Abermann, J., H. Schneider and A. Lambrecht. 2007. Analysis of surface elevation changes on Kesselwand glacier: comparison of different methods. Z. Gletscherkd. Glazialgeol., 41, 147-167.

Auer, I. and 31 others. 2007. HISTALP - historical instrumental climatological surface time series of the Greater Alpine Region. Int. J. Climatol., 27(1), 17-46.

Bätzing, W. 2002. Leitideen für eine nachhaltige Tourismusentwicklung im Ötztal/Tyrol. In Luger, K. and F. Rest, eds. Der Alpentourismus. Innsbruck, etc., Studien-Verlag, 465-489.

Bätzing, W. 2003. Die Alpen. Geschichte und Zukunft eine europäischen Kulturlandschaft. München, Verlag C.H. Beck.

Behm, M., G. Raffeiner and W. Schöner. 2006. Auswirkungen der Klima- und Gletscheränderung auf den Alpinismus. Vienna, Umweltdachverband.

Beniston, M. 1997. Variations of snow depth and duration in the Swiss Alps over the last 50 years: links to changes in large-scale climatic forcings. Climatic Change, 36(3-4), 281-300.

Beniston, M., B. Uhlmann, S. Goyette and J.I. Lopez-Moreno. In press. Will snow-abundant winters exist in the Swiss Alps in an enhanced greenhouse climate? Int. J. Climatol. (10.1002/ joc.2151.)

Breiling, M. and P. Charamza. 1999. The impact of global warming on winter tourism and skiing: a regionalised model for Austrian snow conditions. Reg. Environ. Change, 1(1), 4-14.

Derksen, C. and E. LeDrew. 2000. Variability and change in terrestrial snow cover: data acquisition and links to the atmosphere. Progr. Phys. Geogr., 24(4), 469-498.

Diolaiuti, G.A., C. Smiraglia, M. Pelfini, M. Belo, M. Pavan and G. Vassena. 2006. The recent evolution of an Alpine glacier used for summer skiing (Vedretta Piana, Stelvio Pass, Italy). Cold Reg. Sci. Technol., 44(3), 206-216.

Fahey, B., K. Wardle and P. Weir. 1999. Environmental effects associated with snow grooming and skiing at Treble Cone Ski Field. Part 2: Snow properties on groomed and non-groomed slopes. Sci. Conserv., 120B, 49-62. 
Fauve, M., H. Rhyner and M. Schneebeli. 2002. Preparation and maintenance of pistes: handbook for practitioners. Davos, Swiss Federal Institute for Snow and Avalanche Research.

Fischer, A. 2010. Glaciers and climate change: interpretation of 50 years of direct mass balance of Hintereisferner. Global Planet. Change, 71(1-2), 13-26.

Fliri, F. 1992. Schnee in Nord- und Osttirol 1895-1991. Innsbruck, Universitätsverlag Wagner.

Gross, G. 1987. Der Flächenverlust der Gletscher in Österreich 1850-1920-1969. Z. Gletscherkd. Glazialgeol., 23(2), 131-141.

Hantel, M., M. Ehrendorfer and A. Haslinger. 2000. Climate sensitivity of snow cover duration in Austria. Int. J. Climatol., 20(6), 615-640.

Henderson, G.R. and D.L. Leathers. 2009. European snow cover extent variability and associations with atmospheric forcings. Int. J. Climatol., 30(10), 1440-1451.

Hoinkes, H. 1970. Methoden und Möglichkeiten von Massenhaushaltsstudien auf Gletschern: Ergebnisse der Messreihe Hintereisferner (Ötztaler Alpen) 1953-1968. Z. Gletscherkd. Glazialgeol., 6(1-2), 37-90.

Kendall, M.G. 1955. Rank correlation methods. London, Griffin.

Kuhn, M., E. Dreiseitl, S. Hofinger, G. Markl, N. Span and G. Kaser. 1999. Measurements and models of the mass balance of Hintereisferner. Geogr. Ann., 81A(4), 659-670.

Lambrecht, A. and M. Kuhn. 2007. Glacier changes in the Austrian Alps during the last three decades, derived from the new Austrian glacier inventory. Ann. Glaciol., 46, 177-184.

Laternser, M. and M. Schneebeli. 2003. Long-term snow climate trends of the Swiss Alps (1931-99). Int. J. Climatol., 23(7), 733-750.

Lopez-Moreno, J.I., S. Goyette and M. Beniston. 2009. Impact of climate change on snowpack in the Pyrenees: horizontal spatial variability and vertical gradients. J. Hydrol., 374(3-4), 284-396.

Mann, H.B. 1945. Nonparametric tests against trend. Econometrica, 13(3), 245-259.

McCabe, G. and D. Wolock. 2009. Recent declines in Western US snowpack in the context of twentieth-century climate variability. Earth Interact., 13(12), 1-15.

McCabe, G. and D. Wolock. 2010. Long-term variability in Northern Hemisphere snow cover and associations with warmer winters. Climatic Change, 99(1-2), 141-153.

Olefs, M. and A. Fischer. 2008. Comparative study of technical measures to reduce snow and ice ablation in Alpine glacier ski resorts. Cold Reg. Sci. Technol., 52(3), 371-384.
Olefs, M. and M. Lehning. 2010. Textile protection of snow and ice: measured and simulated effects on the energy and mass balance. Cold Reg. Sci. Technol., 62(2-3), 126-141.

Olefs, M. and F. Obleitner. 2007. Numerical simulations on artificial reduction of snow and ice ablation. Water Resour. Res., 43(6), W06405. (10.1029/2006WR005065.)

Olefs, M., A. Fischer and J. Lang. 2010. Boundary conditions for artificial snow production in the Austrian Alps. J. Appl. Meteorol. Climatol., 49(6), 1096-1113.

Patzelt, G. 1980. The Austrian glacier inventory: status and first results. IAHS Publ. 126 (Riederalp Workshop 1978 - World Glacier Inventory), 181-184.

Scherrer, S.C., C. Appenzeller and M. Laternser. 2004. Trends in Swiss Alpine snow days: the role of local- and large-scale climate variability. Geophys. Res. Lett., 31(13), L13215. (10.1029/2004GL020255.)

Schöner, W., I. Auer and R. Böhm. 2009. Long-term trend of snow depth at Sonnblick (Austrian Alps) and its relation to climate change. Hydrol. Process., 23(7), 1052-1063.

Smiraglia, C. and 6 others. 2011. Glacier changes and their impacts on mountain tourism: two case studies from the Italian Alps. In Orlove, B., E. Wiegandt and B.H. Luckman, eds. Darkening peaks: glacier retreat, science and society. Berkeley, CA, University of California Press.

Steiger, R. and M. Mayer. 2008. Snowmaking and climate change: future options for snow production in Tyrolean ski resorts. Mt. Res. Dev., 28(3-4), 292-298.

Takeuchi, Y., R.B. Kayastha and M. Nakawo. 2000. Characteristics of ablation and heat balance in debris-free and debris-covered areas on Khumbu Glacier, Nepal Himalayas in the pre-monsoon season. IAHS Publ. 264 (Symposium at Seattle 2000 - DebrisCovered Glaciers), 53-61.

Uhlmann, B., S. Goyette and M. Beniston. 2009. Sensitivity analysis of snow patterns in Swiss ski resorts to shifts in temperature, precipitation and humidity under conditions of climate change. Int. J. Climatol., 29(8), 1048-1055.

Wulder, M., T. Nelson, C. Derksen and D. Seemann. 2007. Snow cover variability across central Canada (1978-2002) derived from satellite passive microwave data. Climatic Change, 82(1-2), 113-130.

Würländer, R. and K. Eder. 1998. Leistungsfähigkeit aktueller Photogrammetrischer Auswertemethoden zum Aufbau eine digitalen Gletscherkatasters. Z. Gletscherkd. Glazialgeol., 34(2), 167-185 